RUDOLF ToKes, Wesleyan University: assistant professor.

Joe R. Wilkinson, Graduate School of International Studies. University of Denver: associate professor.
Lea E. Williams, Brown University: professor.

Clifton E. Wilson, University of Arizona: associate professor.

\title{
RESIGNATIONS AND RETIREMENTS
}

Amry Vandenbosch, director of the Patterson School of Diplomacy and International Commerce, University of Kentucky, and chairman of the department there from 1933 to 1958 , retired on June 30 after 39 years of service at the University.

John H. Ferguson resigned the positions of head of the department and director of the Institute of Public Administration at Pennsylvania State University on September 1. He will remain at the University in a teaching capacity.

Donald E. Hayhurst has resigned his associate professorship at West Virginia University.
Stephen O. Lesser resigned from the University of Victoria, B.C., to accept a position with the Department of State.

Rodney L. Motr, Charles Evans Hughes professor of government and jurisprudence at Colgate University, retired on June 30 after 30 yeurs of service. For 27 years he was director of the University's Division of Social Sciences.

Frank Munger resigned his post of chairman of the department at Syracuse University on June 30.

ERnest B. Schulz' has retired from Lehigh University after 38 years of service on the faculty.

\section{IN MEMORIAM}

Richard W. Barron, professor of political science at Longwood College, died July 18, 1965.

The death of Professor Julian Towster, University of California, Berkeley, on April 15, 1965, at the age of 60 , has left a significant void in scholarship in the field of Soviet Studies. A native of Poland, he came to the United States in 1926, studied at the University of Chicago, which awarded him the JD and PhD degrees. His services to the Department of Justice, Office of Strategic Services, and the State Department during the War and subsequently, were notable. He joined the Political Science Faculty at the University of California in 1950. He was the recipient of grants from the Social Science Research Council, the Russian Institute of Columbia University, and the Guggenheim Foundation.

By his voluminous and authoritative writings on the subject of politics and government of the Soviet Union, Professor Towster achieved an eminent reputation as a Sovietologist throughout the United States and abroad. His major work, Political Powers in the USSR, first published in 1948, broke new ground. It was extensively studied and cited and was used for teaching purposes in over one hundred colleges and universities. He was continually active in public affairs, was in demand as a lecturer on Soviet subjects in the lecture hall, on radio and television. At the time of his death he was engaged in the writing of two major manuscripts concerned with the foreign policy of the Soviet Union, and with its con- duct of foreign relations. He is survived by his wife and two daughters.-THE DEPARTMENT of Political Science, University of California.

Professor Eugene Burdick, University of California, Berkeley, died suddenly on July 26, 1965 , having just concluded a year's leave of absence from teaching. He was a native of Iowa, and received his higher education at Stanford and Oxford Universities, earning the Doctor's degree from Magdalen College following residence as a Rhodes Scholar. Trained in psychology (M.A.), he carried his graduate studies further in political theory. He joined the Political Science staff of the University of California in 1950.

During the First World War he served in the Navy (Jr.Cmdr.), and during the Korean War was assigned to the Naval War College, Newport, as Academic Consultant.

Although well known as the author of the $N$ inth Wave, The Ugly American (with William Lederer), Fail Safe, and others, his professional writing is reflected primarily in articles. He was co-author with A. J. Brodbeck of American Voting Behavior (1959). His abiding interest in politics and public affairs led him far afield as a practitioner, lecturer and adviser. He served as consultant to the government on various aspects of foreign policy and as special adviser to the President. He was associated actively with the Dooley Foundation and with HOPE. He is survived by his widow, two daughters and a son.-The Department of Political Science, The University of California. 